\title{
Tools for a Better Liveability in Neighbourhoods: The "Environmental Island" Design Methodology and the Citizen Engagement Process
}

\author{
By Lucia Martincigh* \\ Anna Vincenzonit \\ Marina Di Guida \\ Giovanni Perrucci ${ }^{+}$
}

The constant increase of private vehicular traffic and its arrogant pervasiveness worsened the urban environment liveability in many Italian cities and destroy more and more their true essence. Only in the last thirty-year period, in Europe, there was a marked acceleration in scientific research and policymaking for defining and experimenting traffic calming strategies and measures aimed at improving the level of safety and accessibility, creating more shared spaces and increasing quality of life, especially in neighbourhoods. Lagging behind other European countries, also Italy started to relate the slow speed principle to the liveable district notion; thanks to the New Traffic Code, the concept of «Environmental Island» was introduced: a «single urban zone delimited by the main road network, aimed at restoring urban spaces' liveability». The «Environmental Island» can then be meant as a possibility not only for reorganizing vehicular mobility but also for upgrading residential urban areas and satisfying dwellers' daily life needs. The analysis of limits and possibilities of application demonstrated that the used methodology could take from both scientific and operative viewpoints to interesting results, defining actions' location, priority and range and providing administrations with advice on the opportunity to act. It is indeed the tight interlace between design process, involving technicians, and public consultation process, involving citizens and local administrations, that can achieve success. In order to ensure the effectiveness of this work, a widespread awareness of the need of changing rooted habits, regarding urban space use, has to be developed; this becomes then the best occasion to implement a type of collective education that leads to a more responsible behaviour from the overall sustainability viewpoint. For years, the topic here presented was faced, also featuring pilot studies in Rome, and now is going to become an applied research; indeed, thanks to the collaboration with various stakeholders, a participation process, aimed at defining the implementation of an Environmental Island in one of the oldest and most central districts of Roma: Rione Monti, is currently underway.

\footnotetext{
*Professor, University of Roma Tre, Italy.

'Councillor of the First Borough, Town Municipality of Rome, Italy.

*Postdoctoral Research Fellow, University of Roma Tre, Italy.

${ }^{+}$Postdoctoral Research Fellow, University of Roma Tre, Italy.
} 


\section{Introduction}

Rome, as every western metropolis, is affected by various types of problems which cause a decrease of the urban environment liveability. First of all, the ever growing increase of air and surface temperature, due to the combination of construction materials with great solar radiation absorption and sealed soils with less evaporative cooling, but also to the "urban canyon effect" and waste heat from various sources, causes an overheating of the urban areas, which are up to $6{ }^{\circ} \mathrm{C}$ hotter than the surrounding rural areas: this is the well known Urban Heat Island phenomenon. ${ }^{1}$ Moreover, a huge vehicle flow, with about 1 million 800 thousand vehicles (668.4 cars and 148.2 motorcycles per thousand inhabitants, ${ }^{2}$ ) the high speed and traffic congestion not only increase the risk of accidents but also produce high levels of air and noise pollution, with considerable quantity of pollutants as a direct consequence: in $2016^{3}$ the concentration of nitrogen dioxide had an average value of $67 \mu \mathrm{g} / \mathrm{m}^{3}$ and the amount of PM10 was $30 \mu \mathrm{g} / \mathrm{m}^{3}$, both to be compared with a threshold of $40 .{ }^{4}$ The high presence of pollutants, combined with the high temperature, contributes to worsen the situation and represents a threat for people's health and for the ecosystem. Moreover, because of the disproportionate demand for street parking, motorized mobility has taken possession of most public spaces, reducing slow mobility and the manifold activities that traditionally took place in the public realm, hiding the urban landscape and making the urban spaces unsuitable for other uses. In addition, the widespread arrogance of drivers, lacking of culture and civic sense, endangers the safety of pedestrians and cyclists and their right to move at ease.

A second aspect characterizes the city of Rome, differentiating it from the other metropolises and making its urban environment harder to live in. Besides a large number of people commuting to work from the suburbs and farther origins, huge masses of people crowd everyday the streets, for two main reasons: on the one hand, the presence of various government institutions like ministries attracts workers, public officials and also people demonstrating and protesting; on the other hand, the presence of a lot of historical and archaeological attractions, but above all the Vatican and the enormous amount of churches, attract hordes of tourists which pour out into the public spaces of the city, straining the urban liveability once more. Not to mention the Universal Jubilees and other religious, cultural and sport events that unregularly stress the urban structure. ${ }^{5}$

The crowds of people in the public space have significant fallouts on mobility

1. H. Akbari, C. Cartalis, D. Kolokotsa, A. Muscio, A. Pisello, F. Rossi, M. Santamouuris, A. Synnefa, N. H. Wong, M. Zinzi, "Local climate change and urban heat island mitigation techniques - The state of the art," Journal of Civil Engineering and Management (January 2016).

2. ISTAT, 2014.

3. http://www.arpalazio.net/main/aria/sci/basedati/stime_comunali/stime_comunali.php.

4. Both limits are prescribed by Legislative Decree 155/2010.

5. L. Martincigh, R. Bizzotto, R. Seghetti, M. Di Guida, G. Perrucci, "Keeping the city liveable for inhabitants and efficient for tourists: the pilgrimage routes," in Book of Proceedings of the 3rd International Academic Conference on PLACES \& TECHNOLOGIES 2016: Keeping up with technologies to create cognitive city by highlighting its safety, sustainability, efficiency, imeagebility and liveability (ed.) E. Vaništa Lazarević, A. Krstić-Furundžić, A. Đukić and M. Vukmirović (Belgrado: Università di Belgrado, Facoltà di Architettura, 2016), 347-354. 
in a city like Rome, where private means still prevails over public transportation and slow mobility. The public transport system is not able to meet the mobility needs of citizens and large flows of visitors and its efficiency is even diminished by the still reigning car culture and consequent huge private traffic flow. The cycling paths cannot offer an alternative not being yet a real network. It is clear then that the reorganization of mobility should become a priority issue on the town municipality agenda. Rome needs a cultural change and intervention tools aimed at increasing its liveability levels in order to improve its sustainability, in terms of both environment, challenging the UHI (Urban Heat Island) effect, and society, defending its most vulnerable parts, as children, elders and people with reduced mobility (PMR). To summarize, this indispensable change in the mobility system towards the sustainability issues, has the aim of saving energy and territory, decreasing pollution and dangers, ${ }^{6}$ as well as promoting a fairer, healthier and more respectful common public space at the same time. ${ }^{7}$

\section{Strategies for Improving Liveability: The European State of the Art}

Since the 1990s, research activities supported by European Community in various Framework Programs for Research and Development aimed at defining and coordinating strategies and policies, methodologies and measures that combined urban design with mobility and the different aspects of sustainability in order to improve both people's quality of life and the urban environment. This is not the place to outline a complete state of the art but, for the matter at hand, it can be well-timed to refer to those aspects that constituted, in some way or another, the background of the slant of the work presented here.

Some of these research projects, developing design tools and assessment methodologies to promote sustainable mobility by the integration of transport and traffic planning and land use, were organized in the LUTR (Land Use and Transport Research) cluster. ${ }^{8}$ In particular, some COST (Cooperation in Science and Technology) Actions focused on vulnerable road users proposed design methods and actions to improve the quality of the urban environment and increase safety. ${ }^{9}$ The aim was to understand pedestrians' quality needs and increase the performances that urban spaces have to offer them in order to promote pedestrian mobility: accessibility, safety, comfort, intermodality and attractiveness. ${ }^{10}$ OECD publications on city vulnerable road users, and in particular on safety and accessibility of PRM, offer important data and viewpoints on the topic. ${ }^{11}$

6. EPA, U. S. Environmental Protection Agency, Reducing Urban Heat Islands: Compendium of Strategies, Urban Heat Island Basics. 2017. https://bit.ly/2DnkMpB. [Accessed 27 April 2018].

7. C. Socco, Il Piano Urbano di Mobilità Sostenibile. Linee d'azione, indicatori e monitoraggio (Firenze: Alinea editrice, 2009).

8. S. Marshall and D. Banister, Land Use and Transport. European Research towards Integrated policies (Oxford: Elsevier, 2007).

9. D. Fleury, A city for pedestrians: policy making and implementation. Final Report of Cost Action C6 (Luxembourg: Office for Official Publications of the European Communities, 2002).

10. H. Methorst, Pedestrians' Quality Needs. Final Report of Cost Action C358 (Luxembourg: Office for Official Publications of the European Communities, 2010).

11. OCDE, Sécurité des piétons (Paris, 1970); OECD, Circulation routière: la sécurité des 
Most European countries carried out national road-safety programs, funded studies, campaigns and experimentations and started specific national research centres, such as SWOV (Institute for Road Safety Research, NL), TRL (Transport Research Laboratory, UK), BASt (Federal Highway Research Institute, G), INRETS (National Institute for Transport and Safety Research, F) and CERTU (Center for Studies on Networks, Transport, Town Planning and Public Construction, F), VTI (National Road and Transport Research Institute, S), VTT (Technical Research Center of Finland, FI) etc. ${ }^{12}$ This commitment, both cultural and economic, enables the sequence: research, implementation, validation and thence the eventual setting up. The aim is to identify the most effective strategies, policies and interventions in order to inform regulations containing prescriptions, criteria and technical indications.

Manuals and guiding lines for street design consider the negative repercussions of vehicular traffic on the quality of both urban spaces and human activities. Analyses are carried out on transport social costs, considering all of them: monetary, energetic, spatial, ecological, acoustic, injuries and fatalities related. ${ }^{13}$

Since 1988, the European Charter of Pedestrians' Rights lay the foundations for a traffic calming policy. Most of the European countries have adopted this approach to reduce speed, reorganize and upgrade urban public spaces, but each country is characterized by specific aspects. Many Dutch municipalities were among the first to adopt road safety plans, they implemented "Zone 30" and experimented traffic calming measures such as "new style" roundabouts. ${ }^{14}$ In France, the well-known program "Ville plus sûre, quartiers sans accidents" was launched in 1984 with the goal of integrating motorized traffic into urban environments, with due regard to local participation and awareness. The program helped local communities to devise, implement and assess an innovative street design to improve safety and quality of life at the same time. In particular, the street landscape with its perspectives was used to modify users' perception and thence behaviours. The results showed not only a drop in accidents and a decrease in speeds, but also notable effects on social and economic local dynamics. ${ }^{15}$ In Great Britain the DETR (Department of the Environment, Transport and the Regions) fixed the goal of reducing traffic accidents by using specific safety measures on pedestrian crossings (besides zebra, central refuge, pelican and puffin), by promoting safe routes to school and by carrying out a pilot project: "Urban safety project" using an approach called "area-wide safety management".

usagers vulnérables (Paris, 2000); OECD, Piétons: Sécurité, espace urbain et santé (Paris, 2012).

12. M. Pezzagno, "Strade urbane in Europa: interventi a favore della sicurezza nei centri urbani residenziali," Quaderni di sintesi Series, no. 55 (Brescia: ASM - Azienda servizi municipalizzati di Brescia, 2000).

13. H. Monheim and G. Frankenreiter, Town and infrastructure planning for safety and urban quality for pedestrians - State-of-the-art report (Luxembourg: Office for Official Publications of the European Communities, 2000).

14. A. Vis, A. Dijksstra and M. Slop, "Safety effects of $30 \mathrm{Km} / \mathrm{h}$ zones in the Netherlands," in Accident Analysis and prevention, no. 24 (Den Haag: SWOV- Institute for Road Safety research, 1992): 75-86.

15. CERTU, Ville plus sûre, quartiers, sans accidents. Réalisations. Évaluations (Lyon: Ministère de l'Equipement, des Transports et de Tourisme, 1994). 
Finally, DETR issued regulations to design 20mph residential zones, defining the use of traffic calming measures involving changes in street horizontal and vertical alignment (dimension, location etc.) and gates signalizing the entrance to these zones, ${ }^{16}$ and has made a three year monitor project for nine "Home zones" "in which the road space is shared between motor vehicles and other road users, with the needs of pedestrians and cyclists coming first." $" 17$ In Germany a particular attention is given to the most vulnerable users (pedestrians, cyclists, children and older people) especially in residential areas; in six case studies, traffic calming measures were applied and various aspects were analysed such as traffic planning, urban development, effects on the environment and social interests. Traffic calming zones (Tempo 30 Zone) featuring specific entrance and exit signs are widely used nowadays in residential areas. In 1997, the Swedish Government passed a bill on "Vision Zero and the Traffic-Safe Environment" with the goal that no one would be killed or seriously injured within the road transport system and allocated congruent funding. The attention is "on how to make streets more trafficsafe and at the same time eco-friendly, negotiable, pleasant and aesthetically appealing." " Suitable indications were presented in a specific handbook: "Calm streets!", that was aimed to assist local authorities in the planning process to remodel streets contemplating and integrating quality demands and social considerations, environmental improvements and traffic calming countermeasures. This publication gave a new impulse to the traffic calming philosophy in Sweden.

Thanks to all these activities it can be said that a great experience was reached for dealing with problems and proposing possible solutions. In the years, the attention first focused on safety moved to a broader, more systematic view. ${ }^{19}$

\section{A Short Outline of the Situation in Italy}

In line with the EU guidelines, even if with some delay, Italian government issued the National Plan for Road Safety in order to establish an innovative practice and to give some support to pilot projects, both of "hard" and "soft" type. $^{20}$ This plan, updated in 2014, aims at the European target of $50 \%$ fatality reduction by 2020 and underlines, among others, two priority areas of action: urban areas, and vulnerable road users and promotes the implementation of continuous, safe and comfortable pedestrian networks in urban areas, through the control of vehicular traffic and the use of innovative traffic calming measures. Other legislative tools, with different time-frames and levels of application, govern

16. DETR, Safer by design. A guide for road safety engineering (London, 1994).

17. DETR, New directions in speed management. A Review of Policy (London, 2000).

18. V. Brandberg et al., Calm Streets! A planning process for safer, more eco-friendly, pleasant and attractive streets in urban areas (Stockholm: The Swedish association of Local Authorities, 1999).

19. J. Rychlewski, "Street network design for a sustainable mobility system," Transportation Research Procedia, no. 14 (2016): 528-537.

20. For "hard" pilot projects, we mean actions improving infrastructures, for "soft" pilot projects, we mean actions affecting people's behaviour and changing cultural attitudes by awareness raising activities. 
urban mobility and public transport in urban areas with the aim to increase safety, reduce traffic congestion and energy consumptions, abate atmospheric and acoustic pollution, decrease private traffic in favour of collective transport systems, favour alternative transport means and modes. ${ }^{21}$ Among them, the one that is more in line with the goals of the National Plan for Road Safety and more interesting for the matter at hand is the Urban Traffic Plan, prescribed by the New Traffic Code. ${ }^{22}$ This tool aims indeed to reorganize urban mobility at local level, classifying traffic components by the use of a scale of values that puts the pedestrians' requirements in the first place, followed by those of cyclists and collective public transport, and leaves those of parking at the end. It considers various strategies and technical measures to increase the quality of the environment for pedestrians and to guarantee them fluent, continuous and safe pedestrian networks, traffic limited zones, pedestrian traffic privileged zones and

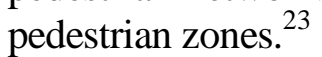

Since 1970s, one of the aspects that is specific of the Italian tradition is the process of pedestrianization of historical areas. It is interesting to notice that this choice was dictated by a primary concern of national policies and strategies: the reduction of pollution from vehicular traffic. This is what has driven most of laws or actions, such as the institution of the "mobility manager" role or the "day without cars" event, and not so much the active promotion of sustainable mobility. The data collected on Italians' daily life do not focus on factors influencing car users' modal choice and behaviour and therefore are not sufficient to identify the factors that could encourage the traveller to shift towards public transport or other smart and green modes of transport, such as cycling and walking. ${ }^{24}$

Even if the promotion of pedestrian mobility is not a main target in Italy, there are laws issued to face other problems that have positive effects also on the walking environment. In particular, this is the case of an innovative law ${ }^{25}$ issued for improving accessibility and use of the urban environment for people with reduced mobility. ${ }^{26}$

Through the participation to EC research activities or networks, such as Car Free Cities or Healthy Cities, knowledge was acquired; unluckily though, there is still a gap between theory and praxis, research and application, legislation and implementation. The reason is that most of the country is still strongly anchored by the car culture. The choices of intervention concern more temporary measures, such as traffic restrictions, than structural interventions or transport means, such as electric cars or car sharing, than the promotion of alternative modal choices, sensitization and change in behaviour. Traffic calming policy is not widespread in Italy but in the North-Central Regions, where there are many more

21. C. Beguinot, Urbanistica e mobilità (Roma: CNR - Consiglio nazionale delle Ricerche, 1999).

22. Legislative Decree 30 April 1992, no. 285 - "Nuovo Codice della Strada", art. 36.

23. M. De Luca and V. Astarita, I piani urbani del traffico (Milano: Franco Angeli, 1998).

24. ISTAT, Aspetti della vita quotidiana 2015. Indagine multiscopo sulle famiglie (Roma, 2015).

25. Decree Law DPR 503/1996 "Regolamento recante norme per l'eliminazione delle barriere architettoniche negli edifici, spazi e servizi pubblici"

26. F. Vescovo, Progettare per tutti senza barriere architettoniche (Rimini: Maggioli, 1997). 
implementations than in the other regions.

In Rome, most of the late upgrading of public spaces and in particular of their accessibility was made in relation with the Great Jubilee, in 2000, and for a minor part with the Extraordinary Jubilee of Mercy, in 2015.

In 2015 Rome Town Municipality drew up the General Urban Traffic Plan (PGTU) that considers a framework of systematic actions, shifting gradually from a logic of mere control and enforcement to one that promotes car and bike sharing, mobility management, public transport, pay and display parking, environmental islands, open data and ICT (Information and Communication Technology) in order to help citizens to make virtuous choices.

Technicians usually are more inclined towards innovation than politicians and implementing bodies; citizens are unsatisfied but are not well aware yet of the appropriate solutions and of the need to change their behaviours too. Last April, on the occasion of the $3^{\text {rd }}$ Meeting of the Safer City Street Network, the global traffic safety network for liveable cities, the technical staff of the Mobility Agency of the Town Municipality presented Rome's Sustainable Mobility Plan (PUMS) and Cycle Network Plan. ${ }^{27}$ Besides the same topics faced by the PGTU, the PUMS considers slow mobility, accessibility for all and monitoring; its main focus is on people and on the satisfaction of their requirements, achievable by a participative process involving citizens and stakeholders. The "red lines" of the plan are the actions on public transport.

\section{The Tool of the Environmental Island}

The specific indications for drawing up Urban Traffic Plans ${ }^{28}$, introduce various possibilities of action, among them: the "Environmental Island" that is applicable in urban residential areas. It is defined as "a single urban zone, delimited by the main road network, aimed at restoring urban spaces' liveability" in which it is possible to consider pedestrians at the core of the mobility planning and give them priority over the other transport modes, reduce private vehicular traffic and control speed in order to improve safety and accessibility, increase pedestrian spaces and their performances with a specific attention to the environmental values. This tool, very innovative for Italy, doesn't contain though specific indications for its thorough implementation. Studies were carried out to precise more its content and define appropriate criteria. The road hierarchy and the distribution network are defined to a greater extent, since the approach derives from Buchanan's Environmental Area, ${ }^{29}$ while the achievement of a good level of liveability needs to be examined in greater depth. The pilot projects that are mentioned in this paper have developed the "district unit" approach: an organizing layout devised by modern urbanism that is based first on a system of spatial

27. Roma Servizi per la Mobilità, Risorse per Roma, Roma Metropolitane. Linee guida del piano della Mobilità Sostenibile di Roma Capitale (Rome, 2017).

28. Ministry of Public Works. "Direttive per la redazione, adozione ed attuazione dei piani urbani per il traffico" - Ordinary Supplement to the Italian Republic Official Gazette no. 146, 24 June 1995.

29. C. Buchanan, Traffic in towns (Middlesex: Penguin Books Ltd, 1963). 
relations between residences and daily facilities. The "district unit" can be considered as a self-sufficient island because residents do not need to exit it for reaching daily facilities on foot. A city rationally organized is a system of "district units" supported by urban and regional facilities, parks, other infrastructures and industrial areas. ${ }^{30}$ It is important then to link closely mobility and urban design, because if the district unit is characterized by environmental quality and liveability, the relation residence-facility can also have a polycentric structure, if appropriate and safe pedestrian and cycle accessibility is guaranteed.

The main criteria that have been applied to identify and define an environmental island (Figure 1) are: the location in an area mainly residential; the road system that is constituted only by local roads; the dimension that is easily walkable $(\max 500 \mathrm{~m})$; the presence of daily facilities; the identification by ideal or actual boundaries; the presence of characteristics that make residents feel a sense of belonging. ${ }^{31}$

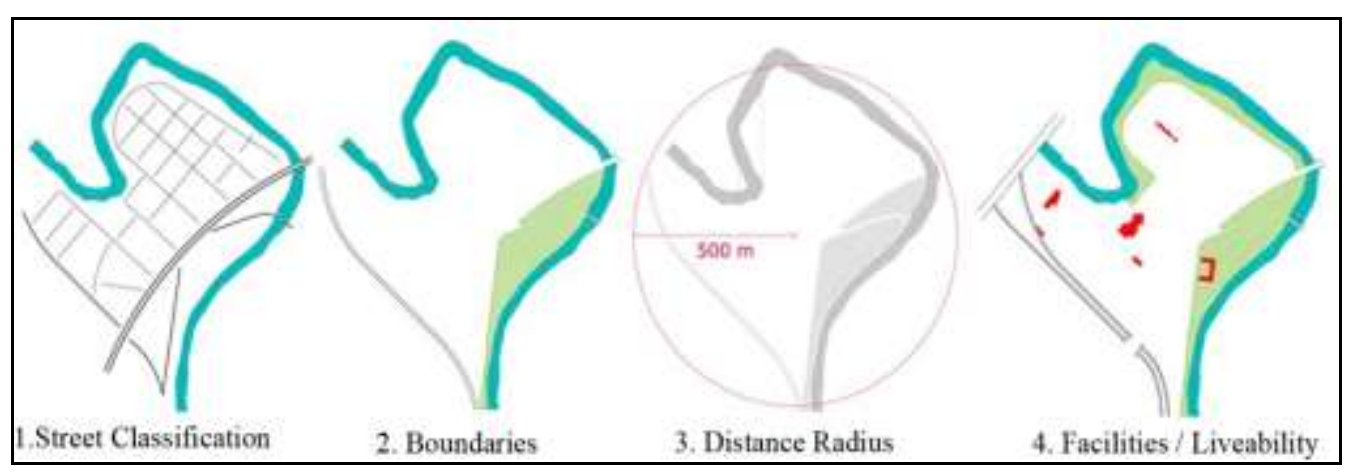

Figure 1. The Application of the Criteria for Identifying a Possible Environmental Island in the District of "Sacco Pastore", Rome

The design of the Environmental Area is characterized by specific aspects: it contains all traffic components but privileges pedestrian and cycling mobility; it applies devices to eliminate through traffic and illegal and non resident parking; it organizes parking facilities for residents, for PMR and for non residents, but only in a minimum amount; it organizes the traffic with a two-way road corridor, serving a multitude of rooms with one-way roads; it applies the $30 \mathrm{~km} / \mathrm{h}$ speed limit and uses traffic calming devices; it designs a continuous pedestrian network, alternating paths and sojourn spaces that are accessible, safe, usable, comfortable and attractive, supported by vehicular mobility; it develops a cycling network that is linked to the main urban one; it locates and designs the intermodal exchange points in an appropriate way; it provides for the delivery of goods with alternative

30. OCS, L'ambito residenziale, la “zona 30” e la normativa italiana. Linee Guida (Regione Piemonte Trasporti - Assessorato ai Trasporti e Infrastrutture Direzione Trasporti - Settore pianificazione dei trasporti, 2006).

31. A feeling that expresses the strong bond existing between individuals and the place where they live can be said to be a "sense of belonging"; Kevin Lynch explains it as the identification with physical landmarks (symbolic places, urban recognizable elements, etc.) or with values shared by the community (familiarity with the place, historical memory, etc.); D. Lynch, Progettare la città. La qualità della forma urbana (Milano: Etaslibri, 1996). 
means; it enhances the potentialities of the urban environment and designs self explaining roads.

This new approach to design aims at achieving, beside liveability for all classes of users, higher levels of local sustainability: environmental compatibility and social equity. The Environmental Island then can be integrated in an Agenda 21 local process. ${ }^{32}$ The achievement of these results involves a marked change in the way citizens and specifically drivers use the streets.

The proposal to define an Environmental Island has to be made at the first level of the Urban Traffic Plan. The congruence of this tool needs to be checked with other regional and town planning tools, among the others with the Urban Master Plan, Urban Mobility Plan, Urban Parking Plan and Public Transport Plan. The Environmental Island is then further defined in the Detailed Urban Traffic Plan; at this level the design is subdivided in different parts that consider aspects that are dealt with in other plans too. It is important then to verify its consistency, for example, with the Plan for the Elimination of Architectural Barriers or with the Plan for Urban Accessibility, if existing, or to integrate these contents in its design. It is also necessary to check its congruence with other regional and city plans at environmental level such as: the Plan of Action for Sustainable Energy, Plan for Energy Saving, Plan for Light, Plan for Urban Green, Plan for Acoustic Classification, Regional Integrated Air Plan, Regional Plan for Waste Management. If these plans are not yet drawn up, it is possible to integrate the contents into the Environmental Island design for what is relevant.

The level of design complexity, due to the many analysed topics, different scales, various implicated know-hows and citizens' involvement, takes not only to adopt an analytical and operational methodology, integrating in a synergic way the techniques used to plan mobility and those used to design and improve the quality of pedestrian public spaces, but also various kinds of participation methods, such as questionnaires and interviews, focus groups and workshops, visioning and scenarios building.

\section{The Design Methodology}

The methodology applied to identify, define and structure the Environmental Island has been developed and tested in case studies within European and national research, carried out through the years at the Department of Architecture of Roma Tre University. This methodology is based on the requirement/performance approach that is proper of the Architectural Technology sector. It is aimed at investigating the district where the Environmental Island could be potentially

32. Local Agenda 21 is a voluntary consultation process started by a local community with the aim to create local policies and programs that try to achieve sustainable development. It includes the awareness raising, ability strengthening, community participation and partnership development. Local Agenda 21 is specified by the chapter 28 of Agenda 21: a wide action plan of the United Nations regarding sustainable development, which was adopted by 178 governments at the 1992 UN Rio Conference; OCS, Linee guida zone 30. Linea guida 5. Lineamenti metodologici per i piani di zona 30 (Regione Piemonte - Assessorato ai Trasporti e Infrastrutture Direzione Trasporti Settore pianificazione dei trasporti, 2007). 
created in order to define problems and potentialities, analyse people's requirements, identify the most important actions to take and the best measures to implement. The methodology is developed in various phases; the first are devoted to various analytical aspects. Below it is reported a flow diagram to clarify the whole process and how its different steps relate to each other, from input to output (Figure 2).

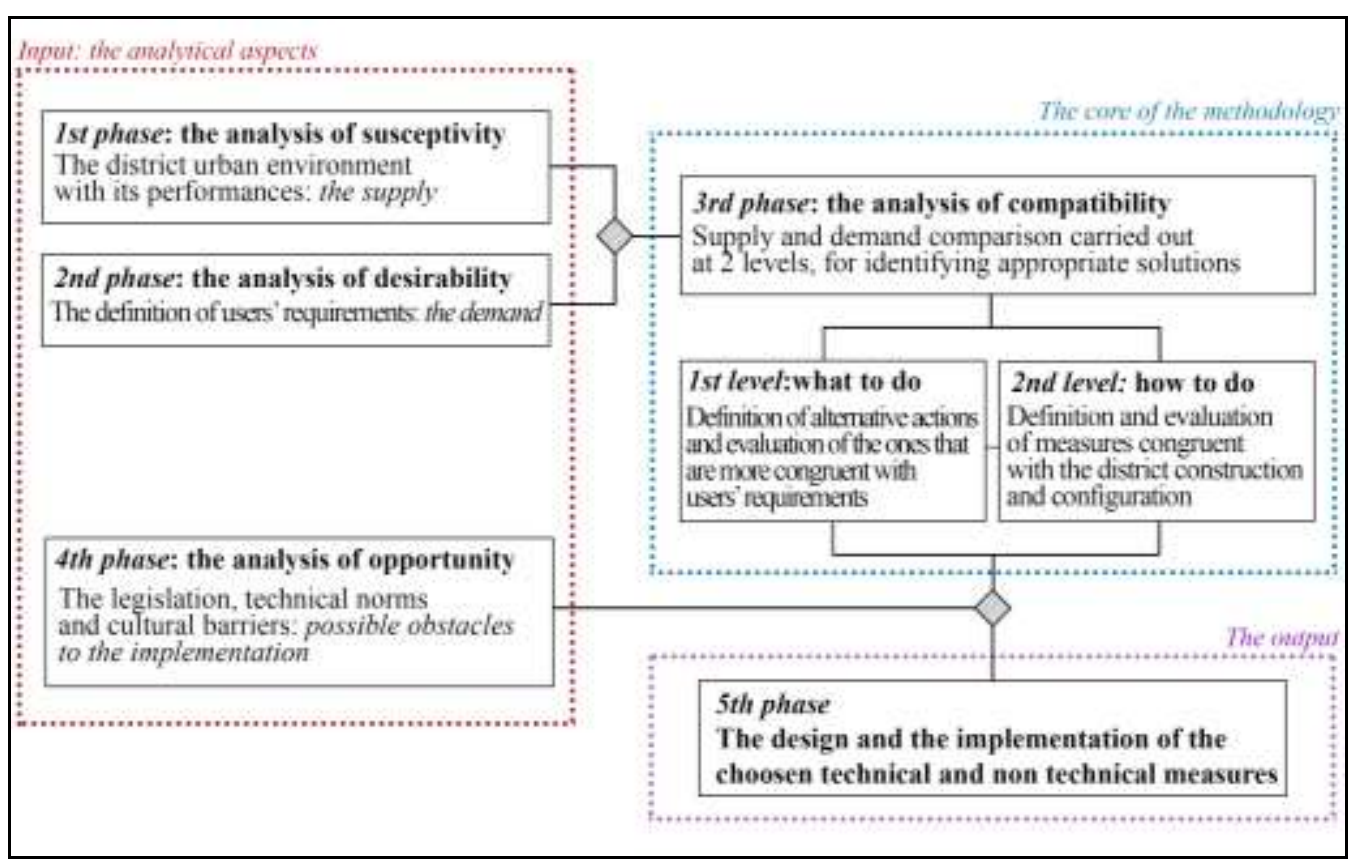

Figure 2. The Design Methodology for the Environmental Island: The Requirement/ Performance Approach

The first phase of the methodology aims at building a picture of the actual situation in the district. By various technical analyses, it studies: the public facilities and their catchment areas; the formal and functional characteristics that shape the three-dimensional street spaces; the consistency and composition of vehicular and pedestrian flows, the type of parking facilities; the public transport lines and interchanges; the environmental features such as the orientation, sun and wind exposure, acoustic levels, tree coverage, views etc. All these data make it possible to define and evaluate the performances that the district offers, using also some indicators of state.

The second phase aims at understanding who are the people living in the district, how they use its public spaces and what are their problems and expectations. The attention is focused on the most vulnerable users, including in this classification all the people with specific needs due to their permanent or temporary conditions or to their age. Various approaches are used to investigate this aspect: the ergonomic configuration, defining the characteristics of the spaces depending on people's activities and their related requirements; the collection of data, statistics, research results etc.; the observation of residents while they use the public spaces to find out their habits and behaviours; the enquiry by questionnaires, interviews, focus groups etc. to find out their opinions; the direct 
involvement of residents in the design process by different techniques: workshop, brainstorming, visioning etc. Specific attention will be paid to the participation theory in another paragraph. All these operations make it possible to define and assess people's requirements.

The third phase, that is the most interesting, consists of two levels of comparison and evaluation of the compatibility of the transformations. The first level considers the comparison between residents' demand and district's offer that defines the list of actions to take to meet residents' requirements. The second level of comparison concerns the selection among appropriate alternative solutions and measures; this is made by the comparison to the construction/configuration of the spaces.

The fourth phase concerns the analysis of the legislation and technical norms to be respected and possible obstacles to the future intervention. It offers then further elements to evaluate the opportunity of action and the choice of solutions.

The fifth phase faces the design of the chosen technical solutions and focus the attention on specific innovative methods tested in previous European research such as for example the definition of: the path that is most used by residents to reach facilities; the residents' crossing demand in connection with facility attraction and the priority and weight of the intervention to be made in connection with traffic speed. ${ }^{33}$ For the choice of the interventions the method refers to indicators or indexes of various type; some of them have been defined in previous European or national research activities such as for example: the level of accessibility of everyday facilities and of public transport interchanges, based on their catchment areas and detour ratio, of sidewalks and crossings, based on specific physical and functional parameters; the sidewalk-carriageway ratio; the type and extent of parking facilities in the district. ${ }^{34}$

Specific methods are used to assess the priority of action based on residents' level of satisfaction and importance; this is very useful to help local administrations in understanding which are the prior problems to solve. ${ }^{35}$

Also the choice and definition of the solutions and measures to apply are guided by the results of some previous European research that defined their appropriateness and agreeableness for pedestrians and vulnerable users. ${ }^{36}$ In particular, for sidewalk design reference is made to the organization per functional stripes depending on the hosted activities and the type of urban area, ${ }^{37}$ for improving accessibility of sidewalks, crossings and bus stops reference is made to

33. K. Rauhala et al., New means to PROMote Pedestrian Traffic in cities-Summary of the PROMPT project and its results (Roma: Di Virgilio, 2003).

34. L. Martincigh, Sustainable mobility: a toolbox for design assessment (Roma: DEI, 2009); Martincigh, Strumenti di intervento per la riqualificazione urbana (Roma: Gangemi, 2012).

35. L. Steg, J. De Groot, S. Forward, C. Kaufmann, R. Risser, K. Schmeidler, L. Martincigh and L. Urbani, "Assessing Life Quality in Transport Planning and Urban Design," in Land Use and Transport. European Research towards Integrated policies (ed.) S. Marshall and D. Banister (Oxford: Elsevier, 2007).

36. Martincigh, Mobility and Quality of life for senior citizens. Indications to improve the use of the urban environment (Roma: DEI, 2011).

37. E. Vanderslice, Portland Pedestrian Design Guide. Office of Tran- sportation, Engineering and Development Pedestrian Transportation Program (Portland, City of Portland, 1998). 
specific measures defined depending on technical norms $;{ }^{38}$ for defining the most appropriate intersections and traffic calming measures reference is made to European best practice. ${ }^{39}$

\section{First Applications of the Environmental Island Methodology}

Thanks to positive synergies between research and teaching, the application of the methodology was possible and some project proposals for the city of Rome have been elaborated.

The first case study is an intervention proposal elaborated in the research "Urban regeneration and pedestrian mobility"; the preliminary analysis and design phases have been examined in depth also thanks to the support of the Municipality of Rome. The analysed area is the neighbourhood of "Pietra Papa", a semiperipheral residential district built in the 1960s, intensely inhabited, in which problems related to the absence of urban quality, intense private mobility and a high amount of parking, with a consequent high atmospheric and acoustic pollution and some physical and functional degradation, were detected. Pedestrian mobility has been proposed as a tool of urban renewal and a proposal, taking into consideration the use of public urban "empty" spaces to rebalance vehicle mobility, has been set up. The main axis of the pedestrian network, a central road of the area, assumed the role of a "piazza" (square) and was connected with a minor transversal axis, next to the school, a new meeting point for youngsters and elderly, for constituting a system that solves the lack of centrality, meets the need for a space promoting social and cultural relations and creates acceptable conditions also for vulnerable users (Figure 3).

The second case study is represented by the "Sacco Pastore" district; in this example the identification and delimitation of the Environmental Island are practically built-in thanks to the orography of the area which has influenced the urban development of the neighbourhood. The whole district is bordered by the river Aniene and the green belt flanking it, however, the Via Nomentana, an important arterial road, heavily congested, cuts the district in two, creating a strong hindrance between a more naturalistic area, characterized by a thick Roman pine wood, and the rest of the district. The goal of the renewal project is to start up again the continuity between the inhabited and consolidated part of the district and the most natural one, organizing vehicular mobility by traffic calming measures and fostering slow mobility (Figure 4).

38. M. Di Sivo, E. Schiavone and M. Tambasco, Barriere architettoniche. Guida al progetto di accessibilità e sicurezza dell'ambiente costruito (Firenze: Alinea, 2005); CERTU, Les bus et leurs points d'arrêt accessible à tous. Guide méthodologique (Lyon: Ministère de l'Équipement, des Transports et du Logement, 2001).

39. CERTU, Carrefours urbains. Guide (Lyon: Ministère de l'Équipement, des Transports et du Logement, 1999); A. Sanz Alduán, Calmar el trafico (Madrid: Ministerio de Obras Públicas, Transportes y Medio Ambiente, Centro de Publicaciones, 1996). 


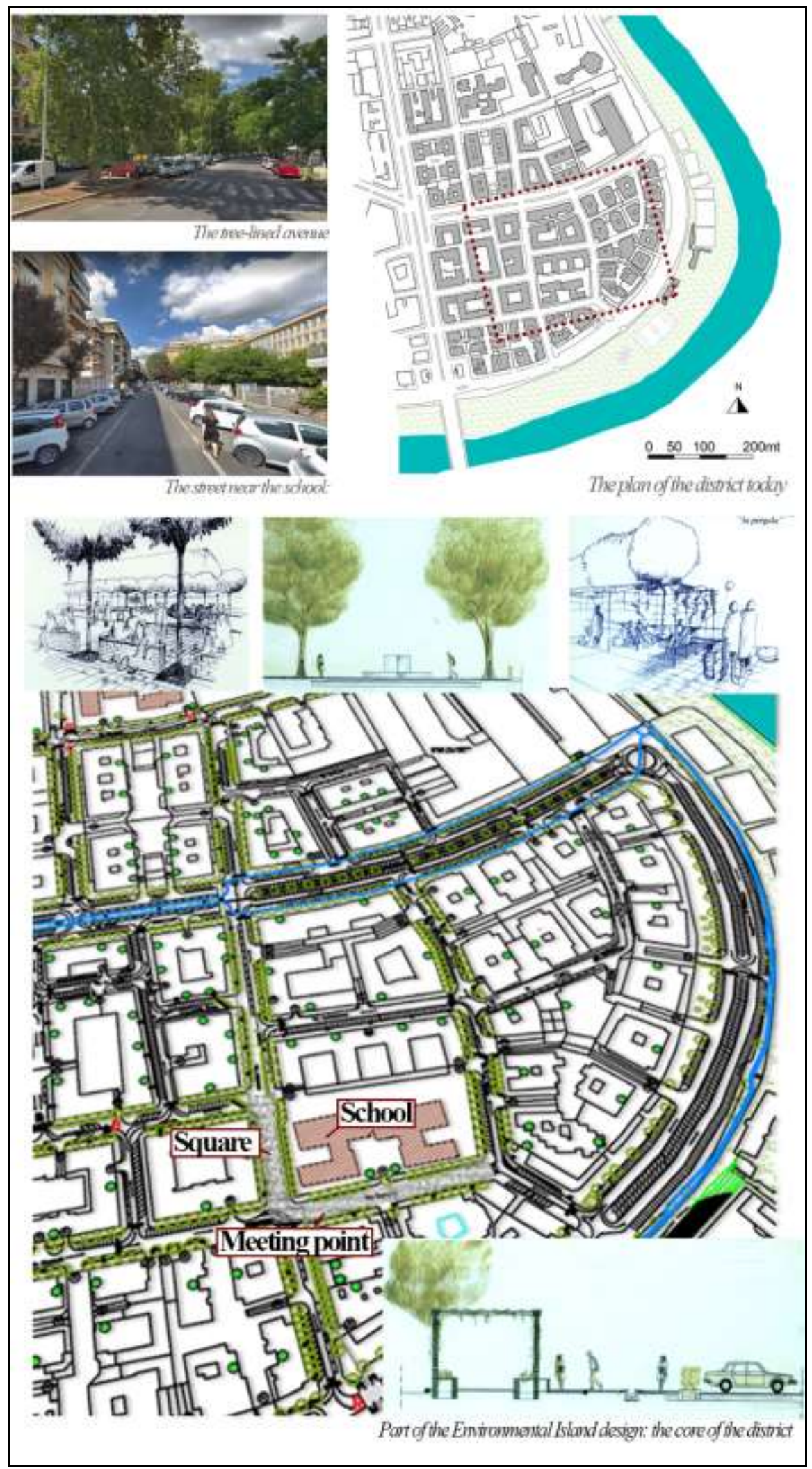

Figure 3. The Pietrapapa Neighbourhood 


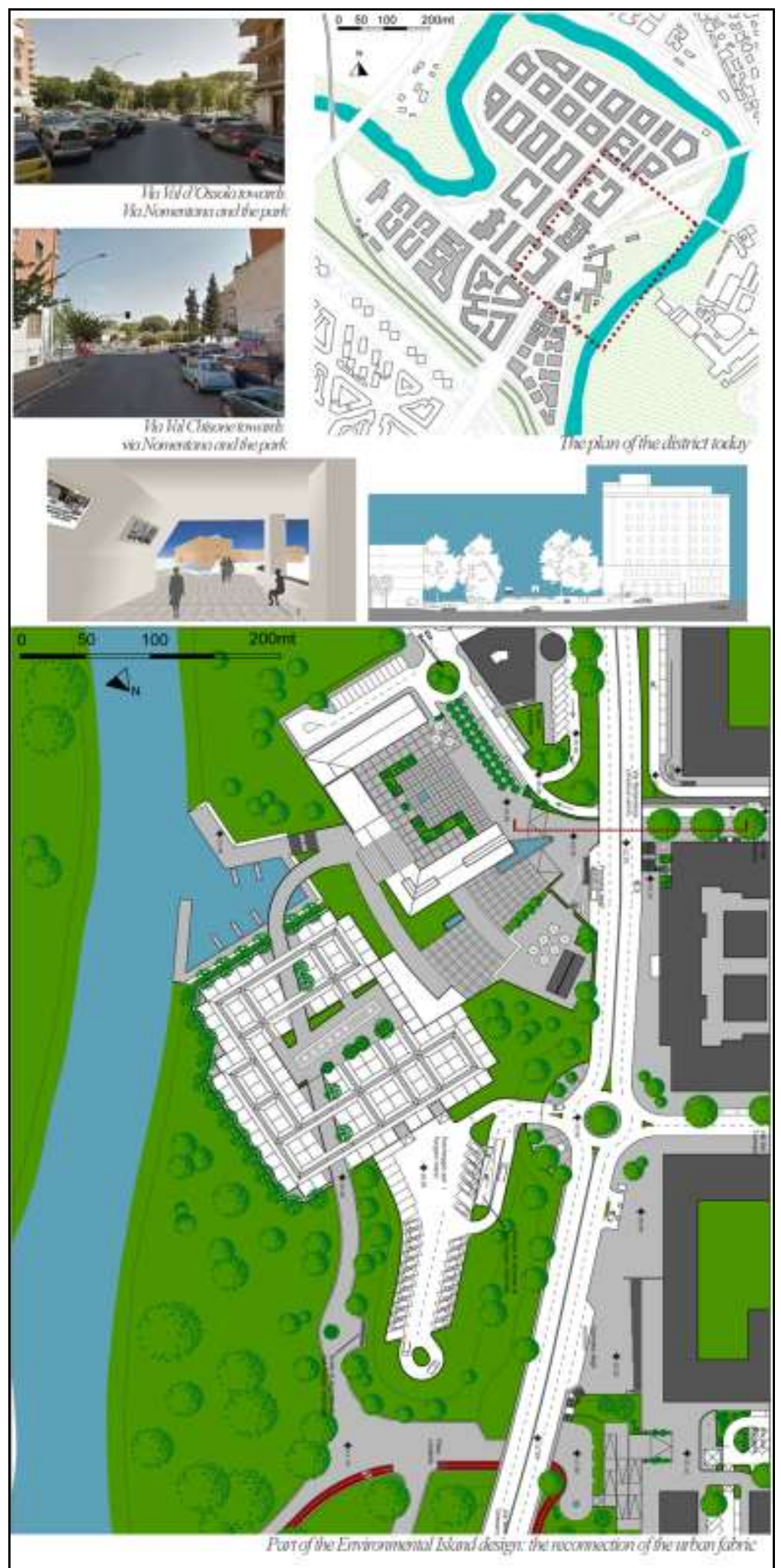

Figure 4. The Sacco Pastore Neighbourhood ${ }^{40}$

40. The contents of the table are based on the Laurea degree design of Manuela Sasso; the drawings have been edited by Marina Di Guida. 


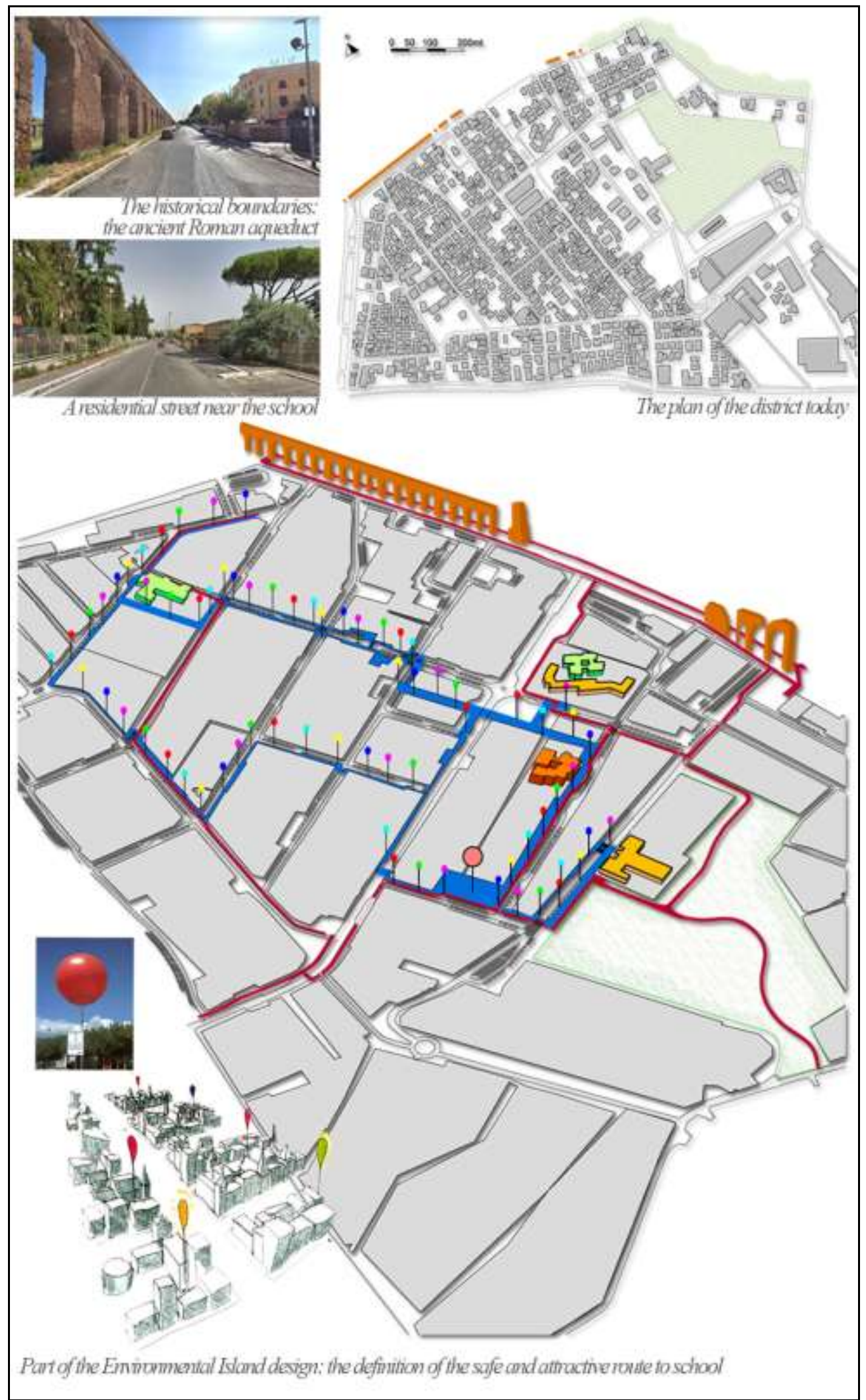

Figure 5. The Alessandrino Neighbourhood ${ }^{41}$

41. The contents of the table are based on the Laurea degree design of Natalia Iacopino; the 
The third case study is represented by the "Alessandrino" district, a very suburban neighbourhood, which is characterized by an important city artery, the Via Casilina, and the ancient Roman aqueduct, the Aqua Alexandrina. The analysis of the territory brought to the delimitation of a macro area which, however, includes different realities from orographic and architectural viewpoints. Through the study of the internal road layouts, some micro-zones were identified, each with daily services. The interventions for this case study had the aim of: rebalancing the vehicular traffic; setting up a pedestrian mobility system playing the role of connective tissue between the centres of attraction of the district; implementing measures for guaranteeing accessibility, safety, comfort and the place identity for both residents and outsiders (Figure 5).

The last case study is the district of "Valco San Paolo", a settlement bordered by an important road, the Viale Marconi, and enclosed by the Tiber River raised banks, making up a sloped green belt. The district was an important industrial area; most of its buildings were abandoned and today reused, in part, by Roma Tre University; residential blocks were built in the 1950s. The well-defined borders, the road system and the identifiable urban structure, the presence of facilities and the specific environmental characteristics took to a proposal of Environmental Island, with the aim of creating a sustainable neighbourhood, with a safer, healthier, more accessible and attractive pedestrian environment. In particular, the project aimed at offering pedestrian paths and spaces that were accessible, to make it possible for all categories of users to reach all the destinations in the area, but also visually and acoustically comfortable (Figure 6). To achieve these objectives and solve the detected problems at the same time, several solutions have been adopted: the paths and pedestrian spaces have been redesigned, according to current legislation on accessibility, equipped with new deciduous trees, positioned according to the study of sunshine and shading, and the existing lighting has been integrated with new fixtures that perform better and enhance the surrounding environment.

drawings have been edited by Marina Di Guida. 


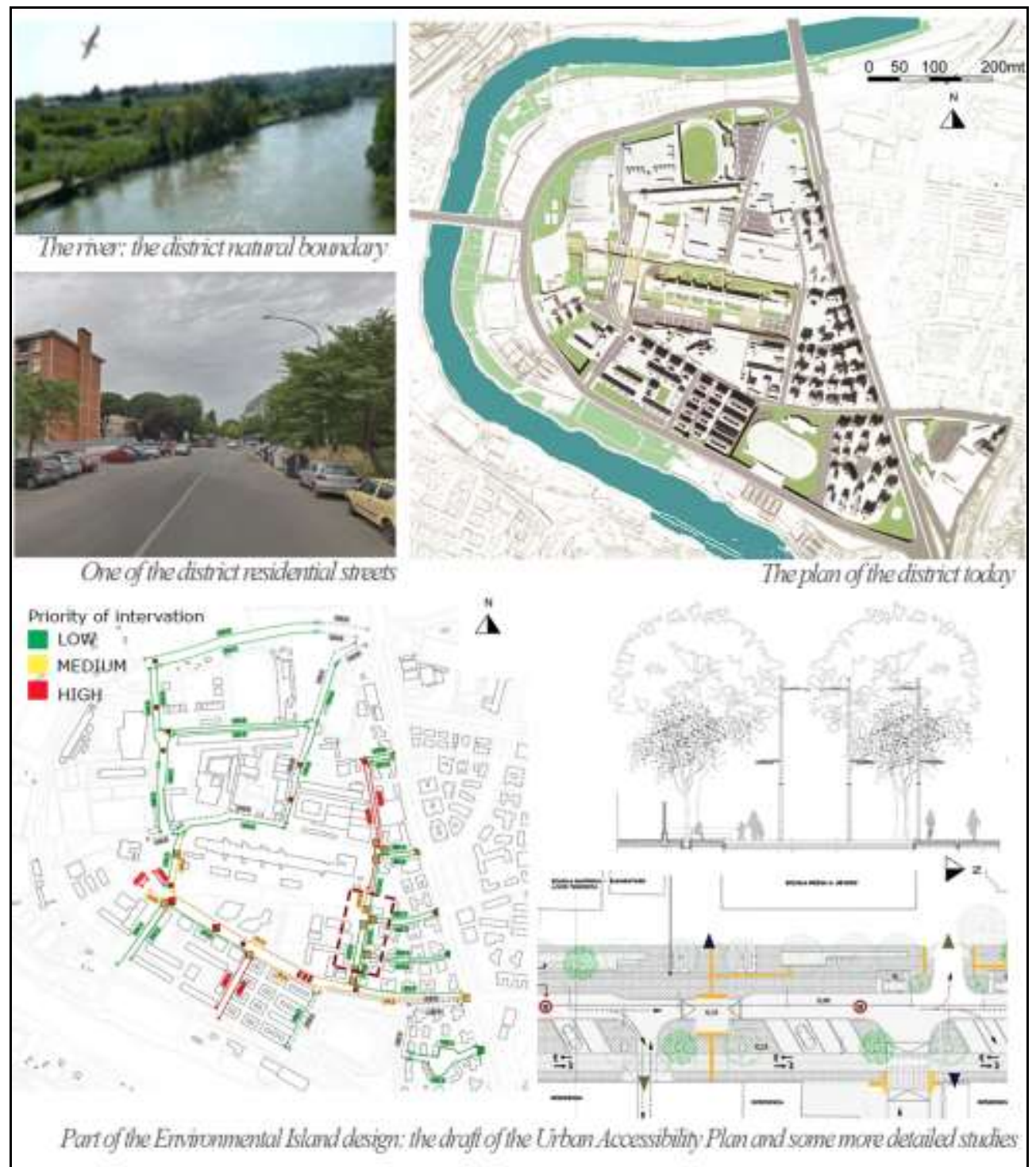

Figure 6. The Valco San Paolo Neighbourhood ${ }^{42}$

\section{The Participation Process: Theory and Practice}

The peculiarity of the methodology proposed here for the Environmental Island design is the tight connection between the planning process and the citizens' involvement, considered as an essential act to ensure its success. The project of the Environmental Island, to be effective, must indeed be accompanied by the citizens' awareness of the need to change their habits and behaviours, by now rooted, in using urban spaces. ${ }^{43}$

42. The contents of the table are based on the Environmental Island designs drawn up within the Course of "City and Environment" (2012-'13), prof. arch. Lucia Martincigh, Master Degree in Urban Design, Department of Architecture, Roma Tre University; the drawings have been edited by Marina Di Guida.

43. L. Staricco, "Multifunzionalità e conflittualità nelle Zone 30," TeMA trimestrale del 
The involvement of citizens in public decision-making processes has been widespread in many countries for several decades. Starting from the social movements of the second half of the twentieth century that pushed citizens to participate in decision-making, theory and practice were developed in different national contexts: from the "Citizens' Assembly", which proposed a reform of the electoral system in the Canadian province of British Columbia, to the public consensus conferences in Denmark set to evaluate the consequences of the use of new technologies; from the design of a sustainable city prototype, based on cooperation, in Geraldton, Australia: "Geraldton 2029 and beyond", to the launch of a regional development policy based on dialogue in Portsmouth, USA: "Portsmouth listens"; from the participation at the base of the deep reforms of the public administration in Christchurch (New Zealand) and Kerala (India), to the birth of the first participatory financial report in Porto Alegre (Brazil) and in La Plata (Argentina), to the local initiatives to promote the social engagement in the disadvantaged neighbourhoods of many European and North American cities. In the last fifty years, numerous "bottom-up" institutions and organizations have worked all over the world for the institutionalization of participatory processes, for example: the "Stiftung Mitarbeit" (Mitarbeit Foundation), which since 1963 promotes the bottom-up development of democracy in Germany; the "Österreichische Gesellschaft für Umwelt und Technik" (Austrian Society for the Environment and Technology), a supra-partes platform for the participated administration, which since 1985 promotes participatory processes especially in the environmental policy sector in Austria; the non-profit "Involve" organization, which since 2003 provides information on participatory methods referring to concrete experiences drawn from real practice in the United Kingdom; at the supranational level, the "European Institute for Public Participation" (EIPP), which includes partners in Bremen, Brussels, Luxembourg and Bologna, and the "International Association for Public Participation" (IAP2), an organization founded in 1990 in the United States which, providing consultancy through conferences and publications, deals with training aimed in particular at process managers, offering members a digital platform dedicated to information, comparison and discussion. ${ }^{44}$

Thanks to this wealth of experience accumulated over time and the constant updating and structuring work carried out by national and international organizations, citizens are increasingly participating to express their requests and to influence municipal, regional or national policies. The spreading of these processes has been endorsed and accelerated thanks to the affirmation of two aspects: on the one hand the diffusion of the gender approach, ${ }^{45}$ which aims at including all citizens, on the other hand the diffusion of the use of $\mathrm{ICT}^{46}$ and

Laboratorio Territorio Mobilità e Ambiente 4, no. 4 (2011): 59-68.

44 P. Nanz and M. Fritsche, Manual of citizen participation. Actors and procedures. Opportunities and limits (Bonn: Bundeszentrale für politische Bildung, 2012).

45 R. Frey, "Interlinking Gender Responsiveness and Participation in Public Budgeting Processes," in Gender Responsive and Participatory Budgeting (ed.) C. Ng (Cham: Springer, 2016).

46 A. Hellsmanns, C. Niemeyer, M. A. Hall, T. Zentek, C. Weinhardt, "Towards a Requirement Framework for Online Participation Platforms," Interdisciplinary Informatics Faculty Proceedings \& Presentations, no. 11 (2016). 
digital tools and technologies (and in particular web 2.0 also called participatory web) that makes an increasing number of citizens participate in real time, not physically but virtually. ${ }^{47}$ In particular, thanks to the gender mainstreaming approach to the city, more humanistic and holistic, the need to put the respect for daily life ways of men and women of all ages at the heart of all political and design decisions is affirmed. ${ }^{48}$ The aim is the achievement of equal opportunities in relation to specific issues such as: accessibility, mobility, safety, environmental comfort, careful use of resources and control of impacts that lead to a higher quality of life and greater environmental sustainability. Moreover, thanks to the rethinking of urban governance, pointed towards "new paradigms" such as the "smart city" or, even more, the "cognitive city", due to the new relationship between technological development, protection of the environment and social change, citizens become real active sensors. ${ }^{49}$ In this capacity, they are at the same time actors and users, informing the city's governance strategies and enjoying the use of urban information at the same time. ${ }^{50}$

In Italy, the culture of participation spread especially in the field of urban redevelopment, social policies and interventions for local development. Starting from some important international documents, such as the "Millennium Declaration" of the United Nations in 2000 (followed and confirmed by the Brisbane Declaration, 2005), in 2001, the constitutional reform of article 118 identified the principle of "horizontal subsidiarity" as the formal recognition of the legitimacy of the active role of citizens in the promotion of initiatives of general interest. ${ }^{51}$ At the same time, the benefits of collaborating with a politically active citizenship was understood by many local political decision-makers, who aim at intercepting the needs and opinions of different sections of the population, using the knowledge present in the territory and identifying possible obstacles to the success of their programs. Experience showed that the active involvement of the population has various positive effects: it increases civic culture by making participants better citizens, more aware, responsible and active in the collective sphere; it makes it possible to achieve shared and more stable choices as they incorporate the interests of the involved communities; it enables conflicts to be managed in a proactively way, reducing their intensity and transforming them into opportunities for identification and implementation of shared choices; it increases the sense of appropriation and the validity of the choices that, adopted through procedures involving the communities rather than through bottom down imposition, turn out to be more acceptable and are perceived as more equitable. ${ }^{52}$ Therefore, the participatory approach, in addition to promoting cohesion and social

47. OECD, "Focus on Citizens. Public Engagement for Better Policy and Services," in $O E C D$ Studies on Public Engagement (2009).

48. H. Jarvis, P. Kantor and J. Cloke, Cities and gender (London: Routledge, 2009).

49. A. Mostashari, F. Arnold, M. Maurer and J. Wade, "Citizens as sensors: The cognitive city paradigm," in Proceedings of 8th International Conference \& Expo on: Emerging Technologies for a Smarter World-CEWIT (New York, 2011), 1-5. 2000)

50. J. Portugali, Self-Organization and the City (Berlin: Springer Science \& Business Media,

51. G. Arena, Cittadini attivi. Un altro modo di pensare all'Italia (Bari: Laterza, 2011).

52. R. Dahl, A Preface to Democratic Theory (Chicago: University of Chicago Press, 1956). 
integration, improves the quality of design and, thanks to procedures with greater transparency, facilitates relations between administration and territory, contributing to the social capital formation, to restoring trust among citizens and between them and the political system, to fighting disaffection, reducing cronyism and corruption from powerful interests at the same time. For this reason, today in Italy we speak more properly of "circular subsidiarity" 53 and of a gradual transition from the "Welfare State" to the "Welfare community" with widespread responsibility. ${ }^{54}$

Since 2006, the Town Municipality of Rome adopted a tool for fostering the dialogue between citizens and administration: the "Rules for citizen participation in urban transformation". Municipalities, jointly responsible with the Central Administration for the concrete implementation of participation processes, play an important role in the application of this instrument. In particular, the "Rome I Centre" borough recently adopted the renewed "Rules for people participation and for the establishment of the Citizenship Laboratory of the Rome I Centre borough", which recognizes civic activism and citizens' participation to the political and social life as a fundamental right and a method for better protecting the general interest and the common good. According to these Rules, participants meet and define the organization of the works by electing the facilitators, even outside the participatory forum, and a coordinating nucleus, which is chaired by the Responsible for the participatory procedure and has the task of coordinating the work of the Forum at all stages of the participatory process up to monitoring.

\section{Some Experiences based on Participation Processes}

Starting from the model developed by the American researcher Sherry S. Arnstein, the so-called "Ladder of Citizen Participation," ${ }^{55}$ it is possible to note large differences between various existing types of participatory processes. The "scale", whose first level is represented by the bottom step, where participation is actually only apparent or manipulated, describes the different levels of participation intensity: from an "apparent participation" (Manipulation and Therapy) to a mere "information" (Informing), conveyed bottom-down, to "consultation" (Consultation), where citizens are simply invited to add comments and information, to "involvement" (Placation), in which citizens are allowed to share their opinions that, however, will not necessarily be taken into consideration, to "cooperation" (Partnership) in which administration and technicians commit themselves to take into account the citizens' opinions, up to "capability" (Delegation) where citizens take responsibility for actions to be carried out; finally, at the last level, there is the complete "commitment" (Citizen Control), in which the decision-making power is completely in the hands of citizens (Citizen Control).

53. A. Bonomi, F. Della Puppa and R. Masiero, La società circolare. Fordismo, capitalismo molecolare, sharing economy (Roma: Derive Approdi, 2016).

54. S. Belardinelli, Welfare community e sussidiarietà (Milano: EGEA-Università Bocconi Editore, 2005).

55. S. R. Arnstein, “A Ladder of Citizen Participation,” JAIP, no. 35, 4 (July 1969): 216-224. 
The research, carried out by the authors of this paper for several years on life quality improvement through urban sustainable design, made it possible to further study, empirically, also some participatory planning experiences, started together with other institutional authorities and still ongoing.

The first of these experiences is the Permanent Laboratory of Participatory Design "The Historical City from a gender viewpoint", established in 2014 by the Department of Cultural Heritage of the Rome and Province Order of Architects; the Laboratory, started from the workshop "The Historical City of Rome: living between past and future", in which over 20 citizens' associations and institutions operating in the territory took part besides the Laboratory technicians. The Laboratory carries out studies aimed at preparing proposals on various topics concerning some pilot actions. The Laboratory, after a first phase of the work in which the problems of the historic centre of Rome were considered, built "future scenarios" with the people help, applying the principles of Open Space Technology (OST) and the rules of Visioning, from which some proposals, assessed in terms of shareability and plausibility, emerged. ${ }^{56}$

The objective of the Design Laboratory is to face the problematic areas and the topics considered most important and urgent, and to communicate publicly to citizens and periodically to the local administration ("Rome 1 Centre" borough of the city of Rome) the strategies to be adopted in order of priority for improving citizens' life quality. For the mobility topic, small actions that can be immediately implemented, reiterated and standardized, at low cost or enforcing existing laws, promoting appropriate behaviours at the same time, have been proposed. These actions are aimed at solving various problems simultaneously. This experience was disseminated in the "Public Space Biennial", held in Rome in 2017. In the Arnstein's ladder, this experience could be classified as a "Placation" process.

Another experience, the authors took part in, bringing together the participatory approach and the application of the Environmental Island tool, was carried out with the PSP (Participated Sustainable Design) association, within the project "Inclusive processes in gender design for the historic city", carried out with regional funds. The research involved citizens in the analysis of a specific area, including Della Vittoria, Trionfale and Prati districts of the "Rome I Centre" borough, for the prefiguration of future scenarios. In particular, the project involved several phases: a first step characterized by the "walking neighbourhood", in which technicians and citizens shared impressions, excerpts of the neighbourhood history, memories, experiences and problems; a second step identified by the initiative "Tales from the future: how do you imagine the public space of your neighbourhood?", in which citizens devised individual future scenarios, featuring the changes they wanted for their everyday life spaces. A third step, still in progress, concerns the elaboration of shared solutions through the practice of "creative confrontation", a method for reaching a shared decision based on divergent needs and viewpoints, facilitating the overcoming of any conflicting choice.

56. L. Chiumenti and R. Poce, La Città Storica da un punto di vista di genere. Primi risultati del Laboratorio permanente di progettazione partecipata di genere per la Città Storica (Roma: Architetti Roma Edizioni. Editrice dell'Ordine degli Architetti P.P.C. di Roma e Provincia, 2016). 
The Department of Architecture of Roma Tre University has been involved in the identification, delimitation and proposal of possible environmental islands in the area. During the participatory process, a series of meetings between citizens and institutions were organized, in order to transform the shared vision into feasible and achievable proposals for increasing citizens' life quality. Also this experience could represent the "Placation" step in the Arnstein's ladder.

\section{The Users' Involvement: Testaccio}

The Urban Traffic General Plan of Rome (Figure 7) has hypothesized some Environmental Islands in the centre of Rome, in two of them citizens' participation is active and the authors have been involved.

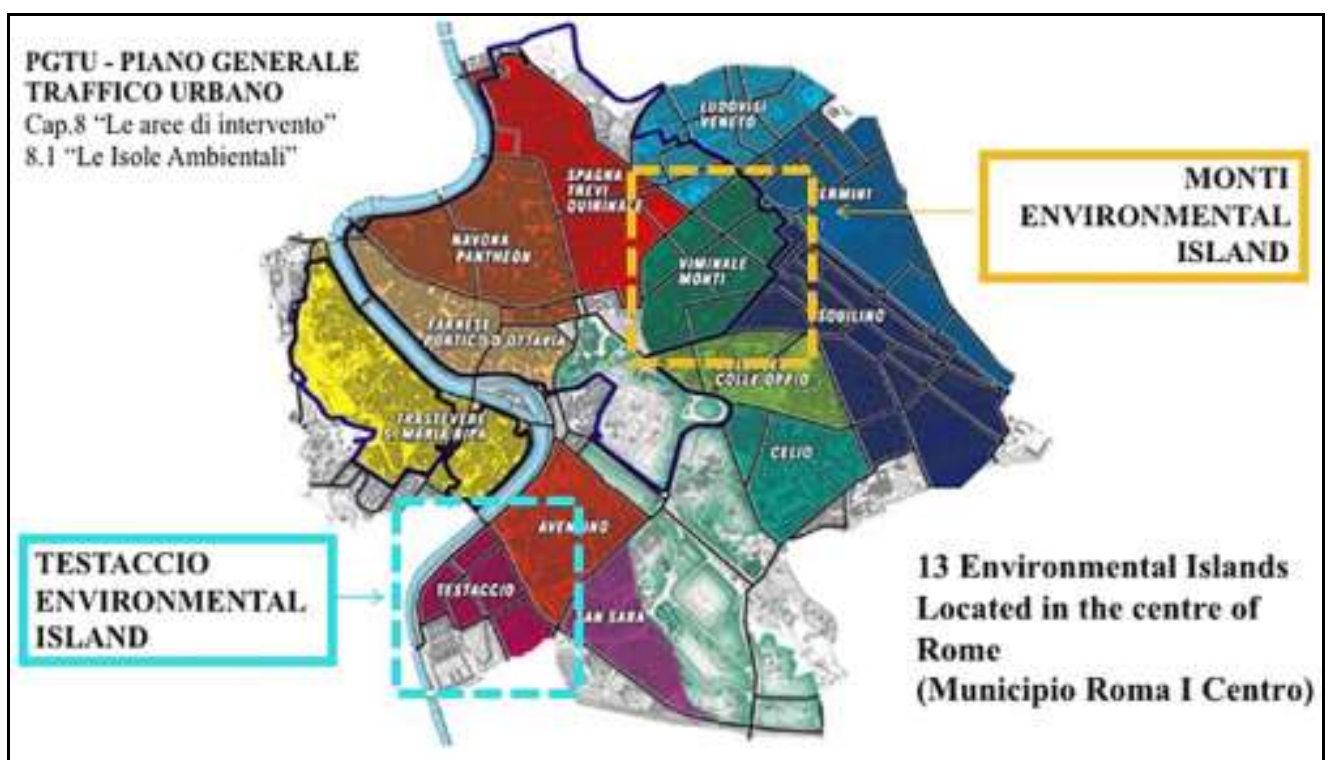

Figure 7. Environmental Islands Hypothesized in the Urban Traffic General Plan - Rome 2015

In one of these districts: Rione Testaccio, located not too far from the Roman Forum, the described methodology has been applied with the aim of designing an Environmental Island. The neighbourhood was built at the beginning of the XIX century, following the construction of the city slaughterhouse; most of the buildings, built as working class housing facilities, still host some social housing and consequently weak portions of the society, as older people. Today, besides its residential function, Testaccio attracts people at an urban scale, above all during the night hours, thanks to its leisure activities: restaurant and wine cellars, cultural facilities such as the "Macro", museum, University, archaeological and historical attractions and an always crowded market.

For the application of the Environmental Island tool, the Department of Architecture has taken advantage of the citizens' direct participation; in the community there is indeed a strong sense of identity and belonging, as demonstrated by the presence of a lot of citizen associations all converging in a 
representative one: Piattaforma Testaccio. This has promoted various bottom-up actions, the most relevant being the reinstatement of an emblematic fountain in its traditional and symbolic place, the "Testaccio Square". The citizen associations" help was essential for analysing the facilities offer and for elaborating the citizen's demand.

The analysis of susceptivity showed how relevant is the issue of accessibility, in a district where a lot of older people live; while the area appears well covered by public transport and its stops, the same cannot be said of all the daily-life services; some of the distances to cover for reaching them are even longer than the required influence radius; moreover, a large part of the paths (up to 36\%) has detour ratios higher than the highest threshold. The pedestrian network is affected by several problems: irregular or uneven paving, due to wrong design or lack of maintenance, which represent a threat to safety; various hindrances, represented by permanent barriers, as trees or streetlamps, or temporary ones, as cars and motorcycles parked on sidewalks, which push users to lengthen their route; inaccessible or difficult crossings, combined with long waiting time at traffic lights, which increase the use effort.

Other problems in the area are related to safety from accidents, related to detected high vehicular speed, and to various aspects of environmental comfort: thermal (extreme summer conditions, due to the street orientation and lack of vegetation or shading devices), respiratory (air pollution, caused by huge traffic flows), acoustic (high noise levels due to vehicular traffic, activities and people), visual (poor artificial lighting in some parts of the area), and hygienic (garbage, bad smells, dirt, above all around the market) comfort.

Starting from these considerations, a priority order of intervention was defined. In order to point out the streets with urgent need of action, some methods were applied: the identification of the most used path that, considering the connections both by ideal routes ("bee-lines") and real paths, between points of origin (residential buildings accesses) and of destination (daily used facilities), helped to point out which are the streets pedestrians use more in their daily movements (Figure 8); the demand for crossing that, considering the type and location of facilities and accesses, helped to define where it is necessary to add new crossings and of what type: "single crossing", "key crossing" (in correspondence of concentrated, relevant user flows where specific design for elevated platforms could be devised) or "crossing anyway along the link" (in correspondence of dense commercial texture where shared spaces instead of single crossings could be proposed) and indicated the priority and weight of the intervention based on the street classification by vehicular speed; the specific indicator assessing the accessibility level of the pedestrian network, sidewalks and crossings, highlighted a situation that asks for a prompt action: only 35\% of sidewalks and $9 \%$ of crossings are indeed totally accessible, while respectively $52 \%$ and $23 \%$ are partially accessible (Martincigh and Di Guida, 2016). ${ }^{57}$

57. L. Martincigh and M. Di Guida, "La mobilità sostenibile come strumento di riqualificazione delle infrastrutture stradali urbane: un approccio metodologico," TECHNE, no. 11/2016 (Firenze: University Press, 2016): 180-187. 


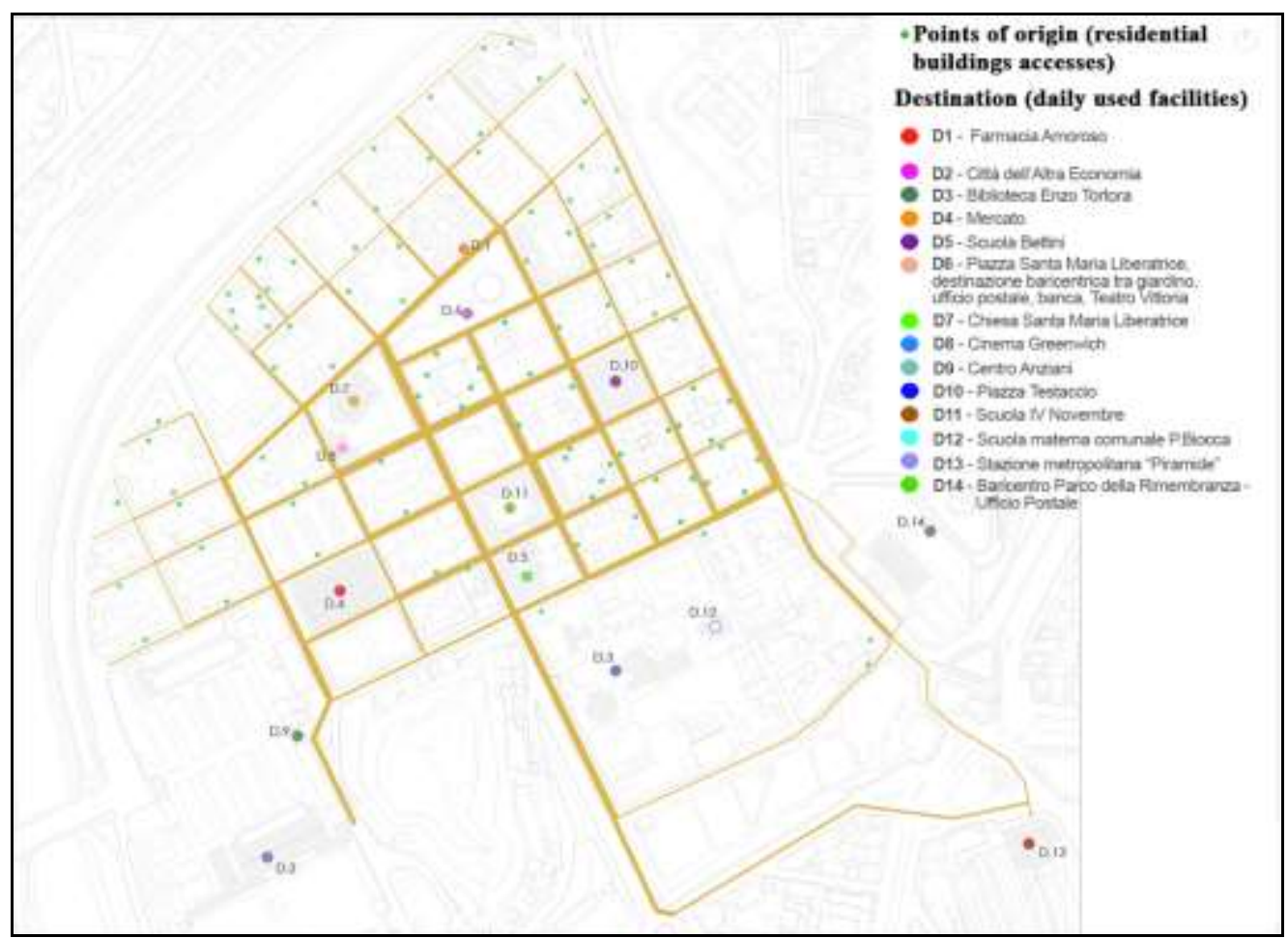

Figure 8. The Methodology of "the Most Used Path" in Testaccio Neighbourhood, Rome

The design proposal dealt with these results and suggested: a general increase of the space dedicated to slow mobility and of its accessibility for pedestrians and cyclists, and in particular for PRM; the use of traffic calming devices for increasing safety and decreasing air and acoustic pollution; the increase of "green and blue" for improving comfort conditions, above all during the summer season. In the Arnstein's ladder this experience could be classified at the "Partnership" level, with citizens' associations and University scholars involved together for meeting inhabitants' requests.

\section{A Participation Process: Monti}

A further planning experience that brings together the Environmental Island theory and the activation of a specific participatory process, as established by the "Rules for citizen participation in urban transformation" of the "Rome I Centre" borough, is going on in the Monti district, one of the oldest and most central districts of the city of Rome, very close to the Coliseum and the Imperial Forums. Despite the presence of numerous institutional offices (including the Bank of Italy), the district managed to keep an artisan vocation until the 1990s, when it was transformed due to the presence of a branch of Roma Tre University but above all to the increase of "dine and dash" mass tourism, which caused many fast food restaurants and souvenirs shops to take the place of typical Roman historical trattorias and workshops. Residents, however, still live the neighbourhood and 
demonstrate a great sense of belonging to the place. As in the pilot case of Testaccio, described above, and in all the historical districts with a strong identity, citizens (residents, artisans and retailers) have gathered in associations with the objective of safeguarding the interests of the different categories and strengthening the sense of community.

The Mobility and Transport Department of the Central Municipality has drawn up a project to establish an Environmental Island in the Monti district, starting from the perimeter identified in 2015 by the Urban Traffic General Plan. The project provides for a Limited Traffic Zone, various traffic calming devices and the pedestrianization of a main street. Some Environmental Island principles, such as accessibility, sustainability and microclimatic control but above all the "urban spaces' liveability", are not included in the project. The residents fear the touristification phenomenon, that is the transformation of their neighbourhood into an exclusively tourist area, as already happened in other districts of Rome (e.g. Trastevere), and the pro-tourism projects that take to the loss of the neighbourhood genius loci (the spirit of a place). They would like that the "spontaneous" spaces of coexistence were maintained and improved, making them more liveable, reducing the invasion of the through traffic flow, the vehicular speed and the spaces devoted to "restaurant dehors". For this reason, the associations asked the borough to start a participation process, carried out within an "Information and public consultation path on the Environmental Island project for Rione Monti" (included in the borough's participation rules), which has the aim of guaranteeing to all the neighbourhood inhabitants both clear information on the urban transformation project and voice in the decision-making process (Figure 9).
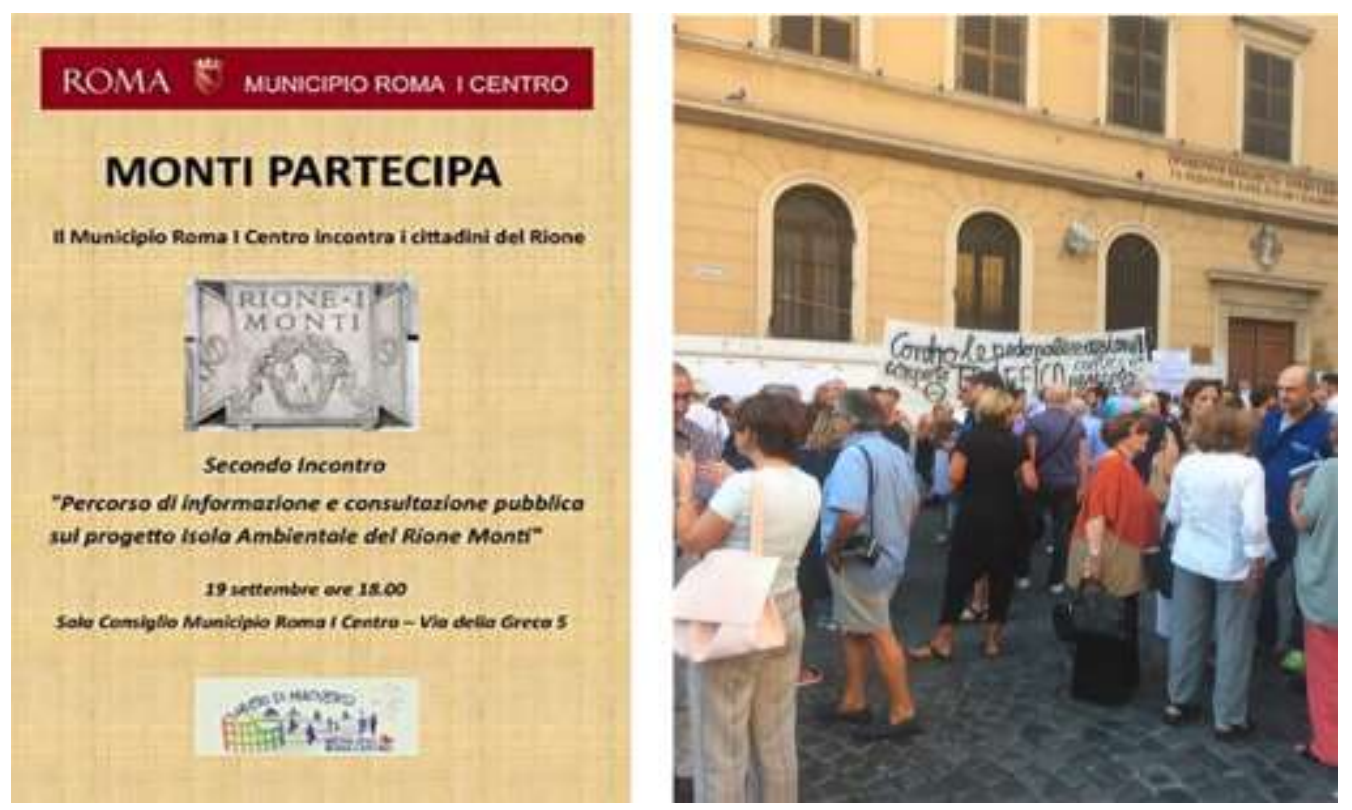

Figure 9. The Participation Process in the Monti Neighbourhood, Rome

The Department of Architecture of Roma Tre University, thanks to its previous research experiences on the Environmental Island topic, has been involved in this process. The value brought by external specialists within the 
process consists not only in their knowledge of the methodologies and in their ability to use them appropriately, but also in their impartiality in an atmosphere sometimes tense, which often characterizes the relationships between administrations and citizens. They represent, therefore, a third party that is competent and neutral at the same time and that makes it possible to replace the citizens/administrators binary scheme with the citizens/administrators/facilitators triangular system. ${ }^{58}$

The process of participation, still ongoing, has been carried out in two ways: directly, through meetings with associations' representatives, experts and borough councillors to discuss the preliminary project proposed by the Central Municipality and collect the opinions, positive and negative, expressed by the various categories (inhabitants, retailers, artisans, commuters, etc.); indirectly, through questionnaires administered online to the neighbourhood inhabitants. All the contributions were recognised by the experts and used in the preparation of the technical opinion provided to the central administration to drive the design towards the citizens' requests and expectations. This type of participatory process is similar to the "Charrette, ${ }^{59}$ carried out in the United States in the context of the New Urbanism trend: a participatory urban planning process in which a multidisciplinary team (made up of citizens, interest groups' representatives, policy makers and experts) works in a collaborative and transparent way to solve issues regarding urban and territorial planning. ${ }^{60}$

\section{Lessons Learnt}

Considering the different situations, problems and opportunities peculiar of each case study where we had the possibility to apply the Environmental Island tool, it is possible to summarize some lessons learnt.

- A general consideration concerns the difference in the application of the Environmental Island tool to the planning of a new area or upgrading of an existing area. In the first case, the indications result easily applicable, but they are applied with great difficulty when the project concern a district that is already built, featuring defined road and public transport network, facilities and rooted uses. Sometimes, the situation shows how some indications of the traffic code and consequently of some other legislative tools and plans are in contrast with the purposes, explicit or implicit, of the

58. G. Pomatto and L. Bobbio, "Il coinvolgimento dei cittadini nelle scelte pubbliche," in Meridiana: rivista di storia e scienze sociali 58 (2007): 45-69.

59. The name Charrette (from the French noun which means "wheelbarrow") refers to the way in which the practical tests were completed in the 19th century at the Academy of Fine Arts in Paris: at that time the examiners ended up affixing the last brushstrokes on their work, often even on the wheelbarrows with which they carried the works to the Academy, accompanied by the people who actively intervened to say their own.

60. Nanz and Fritsche, Manual of citizen participation. Actors and procedures. Opportunities and limits, 2012. 
Environmental Island tool. It emerges then the importance to update these various tools.

Our experience demonstrates, in particular, the importance to update these various tools in order:

- to allow the public transport to pass also through the Environmental Island and then on local roads;

- to allow the downgrade of roads that happen to be inside the delimitation of an area that represents a "district unit", as above defined.

The European Research ARTISTS (Arterial Streets Towards Sustainability) considering that in the past, when there was more compatibility between people's activities and traffic flow and speed, all the conurbations gathered around main streets, and these were lively because as the Romans said: via est vita (street is life), faced the changed actual situation, trying to find a solution different from the bypass one. Today indeed, the same streets host slow and fast mobility that are not compatible anymore, at the same time feature activities attracting people; it is necessary then, taking into account the complexity of the consolidated urban fabric, to redesign these streets to give them back their role of lively spaces and to make the different flows compatible, considering also the possibility for public transport to pass through the Environmental Island using local roads.

- The "Sacco Pastore" application highlighted how it is necessary to consider the district orography, which can take to choose the Environmental Island boundaries regardless of road classification. It shows also the importance of going beyond the indications of the law, that limits to roads the boundaries, taking into account also other infrastructural elements as well as natural, archaeological, historical and architectural ones, how it has demonstrated the case study of the "Alessandrino" district, where the boundaries were identified by a mix of elements: two roads, one hilly park and an ancient Roman aqueduct.

- The relevance of identifying the most active pole/driving element which represents the "core" of the neighbourhood, was the lesson learnt from "Pietrapapa" pilot project. In this case the school was the driving pole but it was also important its interface with other poles and other users (e.g. the elders' centre). This approach helps to identify the pedestrian network and the spaces where it is necessary to act first.

- The "Testaccio" case-study can be considered a pilot project that validates the first part of the methodology on the performance analysis (the supply) and on the citizens' associations involvement by the institutions (highlighting the precise definition of the demand and its possibility of being satisfied). Another relevant topic emerged too. Although the process involved citizens, administrators and experts during its development and arrived to a first definition of the actions to be made, it cannot be said very effective since the borough, the institution closest to the citizens, has no 
possibility to act directly and move to the implementation step because it is not a budget-spending centre. Also in this case it would be necessary to change the law and the organization of the Central Municipality.

- The most recent case study: "Monti", gave important information about the relevance of the citizens' participation. If citizens are not involved and their inputs are not taken into account, the Central Municipality risks not to achieve what had programmed and lose public funding too. Citizens, within their associations, are now mature and have also an institutional instrument, the "Rules" above mentioned, then, if the district inhabitants are not consulted at the start-up phase of the project, but only once the project has been defined, the central administration diminishes its probability of success at the approval and implementation phases. Above all, since the administration has not activated a virtuous circle of "policy capacity,"61 it could also run the risk that local interventions, even if individually effective, cannot be implemented because they are not shared and accepted by the city first users, its inhabitants. ${ }^{62}$

\section{Discussion and Conclusions}

Following the described cases, it is worthwhile to make at least two of the many possible research questions characterizing the topics addressed.

The first research question concerns the possibility to achieve in any case the goals set by the Environmental Island tool. For example, which are the limits and possibilities to apply this tool to the historical districts, characterized by the great complexity resulting from the conditionings of the urban stratification in time (as most of the case-studies described in this essay)?

The second question concerns the participatory processes. While ways and techniques to be used for activating these processes, depending on the peculiarity of the specific cases, are well known, a new line of research to wonder about is: how can anyone carry out participatory processes leading to proposals that are not only shared by citizens and administrators but are also feasible and acknowledged by administrators? How can anyone convince administrators to activate participatory processes providing the "Citizen Control" level?

In the operational reality it often happens indeed that the participatory dimension is too trivialized, confined within the local consultation among representatives, which is not capable of producing sufficient results either in terms of sharing knowledge or of development of collective intelligence.

The challenge is therefore to go to the root of the problem, to investigate participatory planning practices trying to answer the question: "is it really possible to set up participatory projects for the territory?" and therefore "how can the beneficiaries of projects and policies become subjects active in the definition of the

61. M. E. Kraft and S. R. Furlong, Public Policy: Politics, Analysis, and Alternatives (Washington: CQ Press, 2012).

62. E. Ongaro, L'organizzazione dello Stato tra autonomia e "policy capacity," (Catanzaro: Rubbettino, 2008). 
same?"63 Building a "polyphonic"64 vision of the territory, as it is desirable in the participatory planning experiences, means therefore fostering a deliberative and compromise interaction, in which the dialogic exchange between experts and local knowledge is based on the recognition of local subjects as bearers of resources for the project and produces empowerment, encouraging the sustainability of processes and outcomes.

In conclusion, participation is meant as an "art of interactive design", in which the method and the procedure constitute the flexible tools and the legislative references useful for setting processes that are understandable and as transparent as possible.

\section{Bibliography}

Akbari H., C. Cartalis, D. Kolokotsa, A. Muscio, A. Pisello, F. Rossi, M. Santamouuris, A. Synnefa, N. H. Wong, M. Zinzi. "Local Climate Change and Urban Heat Island Mitigation Techniques - The State of the Art." Journal of Civil Engineering and Management (January 2016) DOI= 10.3846/13923730.2015.1111934.

Arena, G. Cittadini attivi. Un Altro Modo di Pensare all'Italia. [Active citizens. Another way of thinking about Italy.] Bari: Laterza, 2011.

Arnstein, S. R. “A Ladder of Citizen Participation.” JAIP, no. 35, 4 (July 1969): 216-224. DOI= http://dx.doi.org/10.1080/01944366908977225.

Beguinot, C. Urbanistica e mobilità. [Urban planning and mobility.] Roma: CNR Consiglio nazionale delle Ricerche, 1999.

Belardinelli, S. Welfare community e sussidiarietà. [Welfare community and subsidiarity.] Milano: EGEA-Università Bocconi Editore, 2005.

Bonomi, A., F. Della Puppa and R. Masiero. La Società Circolare. Fordismo, Capitalismo Molecolare, Sharing Economy. [The circular society. Fordism, molecular capitalism, sharing economy]. Roma: Derive Approdi, 2016.

Brandberg, V. et al. Calm Streets! A Planning Process for Safer, more Eco-friendly, Pleasant and Attractive Streets in Urban Areas. Stockholm: The Swedish association of Local Authorities, 1999.

Buchanan, C. Traffic in towns. Middlesex: Penguin Books Ltd ,1963.

CERTU - Centre d'études sur les réseaux, le transports, l'urbanisme et les constructions publiques. Ville Plus Sûre, Quartiers, sans Accidents. Réalisations. Évaluations. [Safer city, neighbourhoods without accidents.] Lyon: Ministère de l'Equipement, des Transports et de Tourisme, 1994.

. Carrefours Urbains. Guide. [Urban boulevards. Guide.] Lyon: Ministère de l'Équipement, des Transports et du Logement, 1999.

. Les bus et leurs points d'arrêt accessible à tous. Guide Méthodologique. [Buses and their stops accessible to everyone. Methodological guide.] Lyon: Ministère de l'Équipement, des Transports et du Logement, 2001.

Chiumenti, L. and R. Poce. La Città Storica da un punto di vista di genere. Primi risultati del Laboratorio permanente di progettazione partecipata di genere per la Città Storica. [The Historical City from a gender viewpoint. First results of the Permanent

63. E. Saporito, Partecipazione e progetto. La creazione collettiva di senso nelle esperienze di progettazione partecipata (Tesi di laurea, Politecnico di Torino, 2008).

64. The word "polyphonic", typical of a choir, means: different voices which express different viewpoints; it seems then just fitting for the participatory planning. 
Workshop on Participatory Gender Planning for the Historical City.] Roma: Architetti Roma Edizioni. Editrice dell'Ordine degli Architetti P.P.C. di Roma e Provincia, 2016.

Dahl, R. a. A Preface to Democratic Theory. Chicago: University of Chicago Press, 1956.

De Luca, M. and V. Astarita. I Piani Urbani del Traffico. [Urban traffic plans.] Milano: Franco Angeli, 1998.

DETR - UK Department for Transport. New Directions in Speed Management. A Review of Policy. London, 2000. . Safer by design. A guide for road safety engineering. London, 1994.

Di Sivo, M., E. Schiavone and M. Tambasco. Barriere architettoniche. Guida al progetto di accessibilità e sicurezza dell'ambiente costruito. [Architectural barriers. Guide to the accessibility and safety project of the built environment.] Firenze: Alinea, 2005.

EPA, U. S. Environmental Protection Agency. Reducing Urban Heat Islands: Compendium of Strategies, Urban Heat Island Basics. 2017. https://bit.ly/2DnkMpB. [Accessed 27 April 2018].

Fleury, D. A City for Pedestrians: Policy Making and Implementation. Final Report of Cost Action C6. Luxembourg: Office for Official Publications of the European Communities, 2002.

Frey, R. "Interlinking Gender Responsiveness and Participation in Public Budgeting Processes." In Gender Responsive and Participatory Budgeting. Edited by C. Ng. Cham: Springer, 2016.

Hellsmanns, A., C. Niemeyer, M. A. Hall, T. Zentek, C. Weinhardt. "Towards a Requirement Framework for Online Participation Platforms." Interdisciplinary Informatics Faculty Proceedings \& Presentations, no. 11. 2016.

ISTAT - Istituto nazionale di statistica. Aspetti della vita quotidiana 2015. Indagine multiscopo sulle famiglie. [Daily life aspects 2015. Multipurpose survey on families.] Roma, 2015. DOI= https://www.istat.it/it/archivio/91926.

Jarvis, H. P. Kantor and J. Cloke. Cities and Gender. London: Routledge, 2009.

Kraft, M. E. and S. R. Furlong. Public Policy: Politics, Analysis, and Alternatives. Washington: CQ Press, 2012.

Lynch, D. Progettare la Città. La Qualità della Forma Urbana. [Design the city. Urban shape quality.] Milano: Etaslibri, 1996.

Marshall, S. and D. Banister. Land Use and Transport. European Research towards Integrated policies. Oxford: Elsevier, 2007.

Martincigh, L. Sustainable Mobility: A Toolbox for Design Assessment. Roma: DEI, 2009. . Mobility and Quality of life for senior citizens. Indications to improve the use of the urban environment. Roma: DEI, 2011.

_. Strumenti di intervento per la riqualificazione urbana. [Intervention tools for the urban redevelopment.] Roma: Gangemi, 2012.

Martincigh, L. and M. Di Guida. "La mobilità sostenibile come strumento di riqualificazione delle infrastrutture stradali urbane: un approccio metodologico." TECHNE, no. 11/2016. Firenze: University Press, 2016, 180-187.

Martincigh, L., R. Bizzotto, R. Seghetti, M. Di Guida, G. Perrucci. "Keeping the city liveable for inhabitants and efficient for tourists: the pilgrimage routes." In Book of Proceedings of the 3rd International Academic Conference on PLACES \& TECHNOLOGIES 2016: Keeping up with technologies to create cognitive city by highlighting its safety, sustainability, efficiency, imeagebility and liveability. Edited by E. Vaništa Lazarević, A. Krstić-Furundžić, A. Đukić and M. Vukmirović. Belgrado: Università di Belgrado, Facoltà di Architettura, 2016, 347-354.

Methorst, H. Pedestrians' Quality Needs. Final Report of Cost Action C358. Luxembourg: Office for Official Publications of the European Communities, 2010. 
Monheim, H. and G. Frankenreiter. Town and Infrastructure Planning for Safety and Urban Quality for Pedestrians - State-of-the-art Report. Luxembourg: Office for Official Publications of the European Communities, 2000.

Mostashari, A., F. Arnold, M. Maurer and J. Wade. "Citizens as Sensors: The Cognitive City Paradigm." In Proceedings of 8th International Conference \& Expo on: Emerging Technologies for a Smarter World-CEWIT. New York, 2011, 1-5.

Nanz, P. and M. Fritsche. Manual of Citizen Participation. Actors and Procedures. Opportunities and Limits. Bonn: Bundeszentrale für politische Bildung, 2012.

OCDE [OECD] - Organisation de coopération et de développement économiques. Sécurité des piétons. [Pedestrian Safety.] Paris, 1970. DOI= https://bit.ly/2PIdmTz.

Circulation routière: la sécurité des usagers vulnérables. [Road circulation: vulnerable users' safety.] Paris, 2000. DOI= http://dx.doi.org/10.1787/97892642815 78 -fr.

. "Focus on Citizens. Public Engagement for Better Policy and Services." In OECD Studies on Public Engagement. 2009. DOI= http://dx.doi.org/10.1787/20774036.

. Piétons: Sécurité, espace urbain et santé. [Pedestrians: Safety, urban space and health.] Paris, 2012. DOI= http://dx.doi.org/10.1787/9789282103678-fr.

OCS - Osservatorio Città Sostenibili. Dipartimento Interateneo Territorio, Politecnico e Università di Torino. L'ambito residenziale, la "zona 30" e la normativa italiana. Linee Guida. [The residential ambit, the "30" zone and the Italian Law.] Regione Piemonte Trasporti - Assessorato ai Trasporti e Infrastrutture Direzione Trasporti Settore pianificazione dei trasporti, 2006.

. Linee guida zone 30. Linea guida 5. Lineamenti metodologici per i piani di zona 30. [Guidelines for 30 zones. Guideline 5. Methodological features for 30 zones plans.] Regione Piemonte - Assessorato ai Trasporti e Infrastrutture Direzione Trasporti Settore pianificazione dei trasporti, 2007.

Ongaro, E. L'organizzazione dello Stato tra autonomia e "policy capacity". Catanzaro: Rubbettino, 2008.

Pezzagno, M. "Strade Urbane in Europa: Interventi a favore della sicurezza nei centri urbani residenziali." [Urban streets in Europe: interventions promoting safety in urban residential centers.] Quaderni di sintesi Series, no. 55. Brescia: ASM - Azienda servizi municipalizzati di Brescia, 2000

Pomatto, G. and L. Bobbio. "Il coinvolgimento dei cittadini nelle scelte pubbliche." [Citizens' involvement in public choices.] In Meridiana: rivista di storia e scienze sociali 58 (2007): 45-69. DOI= http://digital.casalini.it/10.1400/94491.

Portugali, J. Self-Organization and the City. Berlin: Springer Science \& Business Media, 2000.

Rauhala, K. et al. New means to PROMote Pedestrian Traffic in cities-Summary of the PROMPT project and its results. Roma: Di Virgilio, 2003.

Roma Servizi per la Mobilità, Risorse per Roma, Roma Metropolitane. Linee guida del piano della Mobilità Sostenibile di Roma Capitale. [Guidelines for the Sustainable Urban Mobility Plan.] Rome, 2017. DOI= https://www.pumsroma.it/download/Li nee-Guida-PUMS.pdf.

Rychlewski, J. "Street Network Design for a Sustainable Mobility System." Transportation Research Procedia, no. 14 (2016): 528-537.

Sanz Alduán, A. Calmar el trafico [Calming the traffic.] Madrid: Ministerio de Obras Públicas, Transportes y Medio Ambiente, Centro de Publicaciones, 1996.

Saporito, E. Partecipazione e progetto. La creazione collettiva di senso nelle esperienze di progettazione partecipata [Participation and design. The collective creation of sense in the participation design experiences.] Tesi di laurea, Politecnico di Torino, 2008. URL= http://webthesis.biblio.polito.it/id/eprint/1223. 
Socco C. Il Piano Urbano di Mobilità Sostenibile. Linee d'azione, indicatori e monitoraggio. [Urban Sustainable Mobility Plan. Action lines, indicators and monitoring.] Firenze: Alinea editrice, 2009.

Staricco L. "Multifunzionalità e conflittualità nelle Zone 30." TeMA trimestrale del Laboratorio Territorio Mobilità e Ambiente 4, no. 4 (2011): 59-68.

Steg, L., J. De Groot, S. Forward, C. Kaufmann, R. Risser, K. Schmeidler, L. Martincigh and L. Urbani. "Assessing Life Quality in Transport Planning and Urban Design.” In Land Use and Transport. European Research towards Integrated policies. Edited by S. Marshall and D. Banister. Oxford: Elsevier, 2007.

Vanderslice, E. Portland Pedestrian Design Guide. Office of Tran sportation, Engineering and Development Pedestrian Transportation Program, Portland, City of Portland, 1998.

Vescovo, F. Progettare per tutti senza barriere architettoniche [Designing for all without architectonic barriers.] Rimini: Maggioli, 1997.

Vis, A., A. Dijksstra and M. Slop. "Safety Effects of $30 \mathrm{Km} / \mathrm{h}$ Zones in the Netherlands." In Accident Analysis and Prevention, no. 24 (Den Haag: SWOV- Institute for Road Safety research, 1992): 75-86. 